AL IBTIDA: JURNAL PENDIDIKAN GURU MI (2021) Vol 8 (1) : 116-129

DOI: http://dx.doi.org/ 10.24235/al.ibtida.snj.v8i1.8104

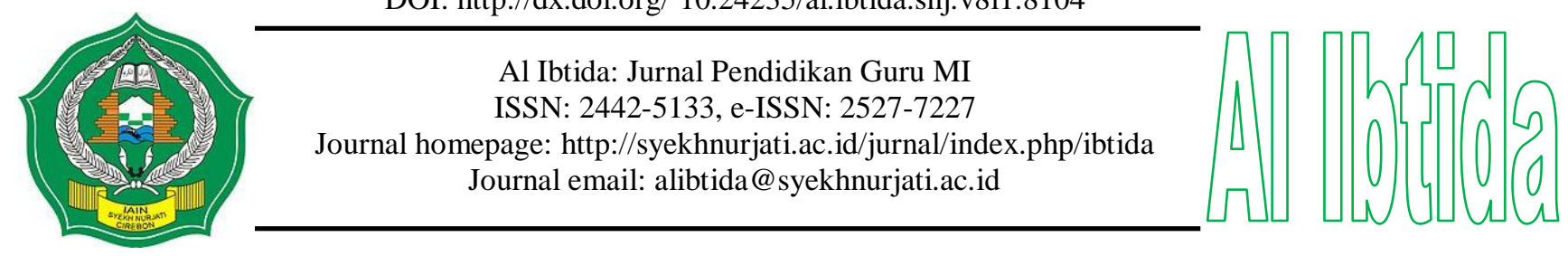

\title{
The Role of Teachers in Internalizing the Values of Local Wisdom in Madrasah Ibtidaiyah
}

\author{
Nuryana* \\ *Department of Social Sciences, Faculty of Tarbiyah and Teacher Training, \\ Institut Agama Islam Negeri Syekh Nurjati Cirebon, Indonesia \\ Email: nuryana@syekhnurjati.ac.id \\ Dede Cahyati Sahrir** \\ **Department of Biology Education, Faculty of Tarbiyah and Teacher Training, \\ Institut Agama Islam Negeri Syekh Nurjati Cirebon, Indonesia \\ Email: dedecahyati@syekhnurjati.ac.id
}

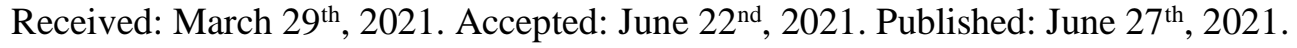

\begin{abstract}
The roles of the teacher in internalizing the values of local wisdom can be seen from the extent of the efforts made by the teacher in developing the values of local wisdom in the learning process. This study aims to describe the roles of teachers and the factors that influence them in internalizing the values of the local wisdom of Cirebon in learning at the Madrasah Ibtidaiyah (Islamic elementary school). A qualitative descriptive study with an ethnographic approach was combined with a quantitative descriptive survey method in this research. Questionnaires, observation, and interviews were utilized to collect data for this study. The findings revealed that instructors' roles in instilling local wisdom values in Islamic elementary school children in Cirebon City had not been fully utilized in the classroom. This can be seen in how the abilities and competencies of teachers who are considered still inadequate to be able to internalize the values of local wisdom in madrasah learning. Local wisdom has so far only been used in the classroom to invite students to tour historical sites, make traditional arts an extracurricular activity, and convey stories about Cirebon's history. Government regulations stating that local wisdom is crucial to its survival and preservation are examples of supporting elements. Teachers, family support, curriculum load, and the cost of visiting cultural sites were discovered to be the most constraining factors.
\end{abstract}

Keywords: teachers' roles; local wisdom; cirebon city; madrasa. 


\begin{abstract}
Abstrak
Peran guru dalam menginternalisasikan nilai-nilai kearifan lokal dapat dilihat dari sejauh mana upaya yang dilakukan guru dalam mengembangkan nilai-nilai kearifan lokal dalam proses pembelajaran. Penelitian ini bertujuan untuk mendeskripsikan peran guru dan faktor yang mempengaruhinya dalam menginternalisasikan nilainilai kearifan lokal Cirebon dalam pembelajaran di Madrasah Ibtidaiyah. Penelitian ini menggunakan penelitian deskriptif kualitatif pendekatan etnografi dikolaborasikan dengan deskriptif kuantitatif metode survei. Teknik pengumpulan data yang digunakan dalam penelitian ini adalah angket, observasi dan wawancara. Hasil penelitian menunjukkan bahwa peran guru dalam menginternalisasikan nilainilai kearifan lokal kepada siswa Madrasah Ibtidaiyah di Kota Cirebon belum maksimal diterapkan dalam pembelajaran. Hal tersebut terlihat pada bagaimana kemampuan dan kompetensi guru yang dinilai masih belum mumpuni untuk dapat menginternalisasikan nilai-nilai kearifan lokal pada pembelajaran di madrasah ibtidaiyah. Selama ini penerapan kearifan lokal dalam pembelajaran hanya sebatas mengajak siswa kunjungan ke tempat bersejarah, menjadikan kesenian tradisional sebagai salah satu ekstrakulikuler dan bercerita mengenai sejarah cirebon saat pembelajaran. Faktor yang mendukung diantaranya adanya kebijakan pemerintah yang menyatakan bahwa kearifan lokal penting untuk dijaga eksisitensi dan kelestariannya. Adapun faktor yang menghambat ditemukan berasal dari guru, dukungan orangtua, beban kurikulum dan juga biaya kunjungan situs budaya.
\end{abstract}

Kata kunci: peran guru; kearifan lokal; Cirebon; madrasah.

\title{
INTRODUCTION
}

The importance of the existence of local wisdom in the current era of globalization is as a filter for global aspects that affect people's lives. This is because local wisdom is a characteristic of a community group in a certain area. Local wisdom can be in the form of rules, activities, or ideas as a guide for community behavior (Jumriani et al., 2021). Character education through education that is based on local wisdom presented in learning is one of the paths that must be taken by teachers (Relin et al., 2018). Teachers must instill character education since basic education so that children have a strong foundation in social life. Strengthening character education through local wisdom needs to be done by teachers so that children are more familiar with the local environment and are more in love with the culture of their nation. Materials that are sourced from children's local wisdom can make learning contextual and meaningful. So, it needs continuous effort and commitment to implement character education based on local wisdom. So that in the end, education in Indonesia has a local eminence of excellence (Mubarok \& Rahmatulloh, 2020).

According to Halim et al., (2018), foreign culture has indirectly harmed local culture. The entrance of western culture into the community without being controlled by the community resulted in a deterioration of the community's indigenous culture. The impact of foreign culture on Indonesia was multi-faceted. Indonesian culture will eventually vanish. Of course, the negative impact is not only that, with developments and changes in terms of food, 
fun, and fashion amid our people's lives, it is also increasingly ensuring that the original culture of our people and nation has been uprooted from its roots (Amsyari, 2016). Therefore, efforts to filter foreign cultures and preserve local culture so that their identity as a nation is maintained and preserved, the process of transformation and internalization of national cultural values, in this case, local wisdom, is a necessity. The inheritance of local wisdom values among the younger generations is important to continue from time to time.

Talking about cultural inheritance, in this case, local wisdom, one of the efforts that can be made as a form of transformation and internalization is through education, namely school. It is through schools that are operationally developed by teachers which are expected to internalize the values of local wisdom among the younger generation, in this case, the students.

The Minister of Education and Culture of the Republic of Indonesia (2014) in the decree (Permendikbud) Number 79 of 2014 concerning the local content of the 2013 curriculum, especially article 2, explicitly explains that local wisdom is so important to be internalized among the younger generation. Through the study of subjects as outlined in local content, it is hoped that students will be able to equip students with attitudes, knowledge, and skills so that they can get to know and love the natural, social, cultural, and spiritual environment in their respective regions. For this reason, education based on local wisdom is expected to be a solution in providing hope for the creation of education that can give meaning to Indonesian human life. Educational institutions which are the main forum for human resource development have a big role and responsibility in the strategic formulation in the internalization of cultural values (Wagiran, 2012). Through education based on local wisdom, students are taught to always be close to concrete and contextual situations in their daily lives. This education will have strong relevance for life skills because it starts with the empowerment of local skills and potentials.

To develop education based on local wisdom, of course, the teacher factor is the main key. In this case, the teacher needs expertise so that he can project various noble values in the learning process. In the learning process, teaching materials should be internalized to the younger generation not only in the form of matters relating to technology science but also material about local cultural values. One way that teachers can do to internalize these values is by explicitly stating the learning objectives, which can be done by stating explicitly in the competency standards (Naryatmojo, 2019).

In the learning process, teachers are required to be able to reflect on the strengths of local wisdom. Learning should be able to answer the challenges of the times by filtering 
foreign cultures and highlighting the local wisdom that we have. In real terms, these important tasks must be carried out by teachers through the learning process. Local wisdom as one of character education has an important contribution in encouraging the formation of a nation's golden generation and has a function to solve various problems of moral degradation among the younger generation (Miller et al., 2005; Leming, 2008; Rokhamana \& Yuliati, 2014; Fatro et al., 2019). According to Sukmadinata (2005), teachers play an important role in planning and implementing the curriculum. A teacher in this case is a designer, implementer and at the same time a curriculum developer for his (Alexon \& Sukmadinata, 2010). Based on some of the findings of previous research, it can be concluded that in the learning process as an effort to internalize the values of local wisdom among students, the ability of teachers as educators and instructors is one of the important factors that is certainly at stake, including in the learning process at the Madrasah Ibtidaiyah.

Cirebon, West Java Province, as one of the major cities in which it stores a myriad of past cultures and histories has the potential to develop local wisdom values in education. Starting from local wisdom in the form of social relations, social life, economy, religion, to art and others, it is important to be internalized among the younger generation. As emphasized by Arovah et al., (2017) that one of the noble values of local wisdom in the city of Cirebon is the wewekas and ipat-ipat Sunan Gunung Jati which contains his thoughts on socio-religious values and practical thoughts to create an open and democratic Muslim society. In addition, in the field of culture, the development of both sacred and profane architecture, for example, the great Cirebon mosque (Sang Cipta Rasa), the palaces (Kasepuhan, Kanoman, Kacerbonan, and Kaprabonan), and sitiingil buildings that adapt local designs and ornaments that have meaning in each symbol (Komariah, 2011). As a form of effort to preserve the values of local wisdom, it can be introduced and instilled in students through the learning process.

The values contained in local wisdom will help students understand each concept not only in terms of mastery of knowledge but can build a love for local diversity in their environment as a provision to become part of the global community (Shufa, 2018; Utari et al., 2016). Therefore, local wisdom is very important to be internalized in Madrasah Ibtidaiyah students because students at that age in the learning process should start with the closest world that students find.

Previous studies related to local wisdom in learning have been carried out by several researchers. Strengthening the values of local wisdom in learning through integration with various models, approaches, and development of teaching materials in various other cities in Indonesia has been attempted by several studies, including research by Hutama (2017) which 
developed social studies teaching materials based on Using cultural values in the form of student learning modules and teacher guide modules in elementary schools. In addition, the cultivation of a culture of anti-violence through local wisdom of traditional games was researched by (Darmawan, 2016), which shows that traditional games are potential local wisdom that can be used as an introduction to anti-violence culture through children's play activities. Excavation of local culture can also be done through art. Gunawan and Sulistyoningrum (2017) explore the local excellence values of Reog Ponorogo art in the form of leadership, aesthetics, and cooperation values. In addition, (Relin et al., 2018) researching local wisdom values in Balinese Folktales, which is the result that the folktales which are suitable to be taught to the first graders at primary school have the following characteristics they teach politeness in speaking, interactions, behaviors, and education. This is done since Indonesians, especially, and other eastern peoples, in general, evaluate our characters and behaviors as those which are polite and those which are not. Specifically, in Cirebon, the research that had previously been carried out was limited to the exploration of local wisdom in the form of the inscriptions of the women and girls of Sunan Gunung Djati (Arovah et al., 2017; Komariah, 2011). Puspitasari (2012) began researching the development of social studies values based on fishermen culture in Cirebon City. However, not many studies have looked at the role of the teacher as an important component of the implementation of a learning process in internalizing the values of local wisdom that exist in society.

In contrast to previous studies, our research focuses on the importance of the impact of the teacher's role in implementing local wisdom in learning in the Madrasah Ibtidaiyah in Cirebon. Departing from this, this study aims to determine how the role of the teacher and the factors that influence it in internalizing the local wisdom values of Cirebon in learning at Madrasah Ibtidaiyah. Whether the teacher's role is consistent or not in the placement of the portion of local wisdom implementation will determine the direction of learning that has a broad impact. The contribution that can be contributed to this research is that it can be used as an initial reference for how prospective teachers or the Madrasah Ibtidaiyah teachers can design learning that is full of noble local wisdom values.

\section{METHODS}

The purpose of this study is to describe how the teacher's involvement in internalizing the values of local wisdom in social studies learning at Madrasah Ibtidaiyah, Cirebon City, using a qualitative descriptive ethnographic technique in conjunction with a quantitative descriptive survey method. Following the above-mentioned research objectives, the research method utilized in this study aims to preserve the object's integrity, which means that the data 
obtained is examined as a whole. The examination of the function of instructors in internalizing the values of local wisdom in social studies learning in the Madrasah Ibtidaiyah, Cirebon City, will be the emphasis in this case.

The subjects in this study consisted of 20 the Madrasah Ibtidaiyah teachers in Cirebon. The considerations that underlie the taking of respondents as stated above are considerations of research time and cost, as well as relatively homogeneous characteristics of respondents so that this number is considered quite representative in providing the required information. The informants selected in this study were based on the purposive sampling technique, in which the sample was taken not depending on the population, but following the research objectives. As stated by Moleong (2014) that the use of the purposive sampling technique is that researchers tend to have information that is considered to know and is trusted to be a solid source of data and to know the problem in depth.

Data collection techniques used in this study were questionnaires, observations, and interviews. Questionnaires were used to obtain information from respondents, in this case, students and teachers, regarding the role of teachers in developing local wisdom-based learning in the Madrasah Ibtidaiyah Cirebon. Observations were made to obtain an overview of the research location, the characteristics of the informants, and the consistency of the development of learning based on local wisdom values at the research site. This observation was conducted to obtain an overview of the research location, the characteristics of the informants, and the consistency of the development of social studies learning based on local wisdom values in the research location. The information obtained through the questionnaire includes 3 dimensions, namely the role of the teacher, supporting factors, and inhibiting factors in internalizing the values of local wisdom in learning at Madrasah Ibtidaiyah. The data analysis technique in this study was carried out with a quantitative formulation approach using a percentage scale. While the data obtained from the interview results were analyzed qualitatively using Miles et al., (2014) through three stages, namely 1) the data reduction stage, 2) the data presentation stage, and 3) the conclusion and data verification stage.

To test how good the quality of the questionnaire instrument is, it will be tested and analyzed at the same time to find out how the quality is in terms of validity and reliability. As for knowing the validity content of the teacher's role variable in internalizing the values of local wisdom in social studies learning at Madrasah Ibtidaiyah Cirebon City, a test was carried out with the computer-assisted SPSS program. Descriptively the result data is referred to in table 1. 
Table 1. Teacher Questionnaire Reliability Value

\begin{tabular}{ccc}
\hline \multicolumn{3}{c}{ Reliability Statistics } \\
\hline & $\begin{array}{l}\text { Cronbach's Alpha Based } \\
\text { on Standardized Items }\end{array}$ & N of Items \\
\hline Cronbach's Alpha &, 707 & 10 \\
\hline
\end{tabular}

Table 1 reveals that the reliability value of the variable questionnaire results is the role of the teacher in internalizing the values of local wisdom, with a score of 0.7 for the questionnaire provided to the instructor. As a result, the questionnaire utilized is trustworthy and practical to use as a research tool.

Table 2. Teacher Questionnaire Validity

\begin{tabular}{|c|c|c|c|c|c|}
\hline \multicolumn{6}{|c|}{ Item-Total Statistics } \\
\hline & \multirow{4}{*}{$\begin{array}{l}\text { Scale Mean } \\
\text { if Item } \\
\text { Deleted }\end{array}$} & \multicolumn{4}{|l|}{ Scale } \\
\hline & & Variance if & Corrected & Squared & Cronbach's \\
\hline & & Item & Item-Total & Multiple & Alpha if Item \\
\hline & & Deleted & Correlation & Correlation & Deleted \\
\hline $\mathrm{X} 1$ & 32,1750 & 5,020 &, 345 & & ,631 \\
\hline $\mathrm{X} 3$ & 32,2250 & 4,743 & , 469 & & ,603 \\
\hline $\mathrm{X} 4$ & 32,2750 & 4,563 &, 556 & & ,583 \\
\hline X5 & 32,1250 & 3,856 & ,663 & & ,479 \\
\hline X6 & 32,0750 & 4,533 & ,304 & & ,571 \\
\hline X8 & 32,1750 & 5,020 & ,445 & & ,631 \\
\hline X9 & 32,2250 & 4,743 &, 569 & & 603 \\
\hline $\mathrm{X} 10$ & 32,2750 & 4,563 & ,456 & &, 583 \\
\hline X11 & 32,1250 & 3,856 & ,663 & & ,479 \\
\hline $\mathrm{X} 15$ & 32,0750 & 4,533 & ,304 & &, 571 \\
\hline
\end{tabular}

In Table 2, a look at the validity of each item shows that of the fifteen questionnaire items distributed to the teacher, ten questionnaires were declared valid, among others; Questionnaire items number 1, 3, 4, 5, 6, 8, 9, 10, 11 and 15. Invalid questionnaire items were declared dropped and the researcher only used 10 valid questionnaires.

\section{RESULTS AND DISCUSSION}

\section{The Role of Teachers in Internalizing Local Wisdom}

Information on how the teacher's role in internalizing the values of local wisdom in social studies learning at Madrasah Ibtidaiyah, Cirebon City was extracted by distributing questionnaires to 20 teachers at Madrasah Ibtidaiyah, Cirebon City. Based on the questionnaire distributed and received from respondents as many as 20 teachers, the analysis and interpretation of the data were obtained as follows. 
Table 3. Recapitulation of Teacher's Role in Internalizing Local Wisdom Values

\begin{tabular}{lccccc}
\hline \multicolumn{1}{c}{ Indicator } & \multicolumn{4}{c}{ Alternative Answers } & \multirow{2}{*}{ Sum \% } \\
\cline { 1 - 5 } & A & B & C & D & \\
\hline Understanding Cirebon local wisdom & 0 & 0 & 85 & 15 & 100 \\
Ability to internalize & 0 & 0 & 90 & 10 & 100 \\
Inculcation in learning & 0 & 0 & 75 & 25 & 100 \\
Introduction to learning & 0 & 0 & 80 & 20 & 100 \\
Strategies filled with local wisdom & 0 & 0 & 90 & 10 & 100 \\
Cultural site visits & 0 & 0 & 70 & 30 & 100 \\
Introduction to music and dance & 0 & 0 & 3 & 97 & 100 \\
Use of community game media & 0 & 0 & 3 & 97 & 100 \\
Learning resources containing local & 0 & 0 & 10 & 90 & 100 \\
wisdom & 0 & 18 & 60 & 22 & 100 \\
Introduction to Cirebon batik & 0 & 18 & 566 & 416 & 100 \\
\hline \multicolumn{1}{c}{ Sum } & 0 & 1,8 & 56,6 & 41,6 & 100 \\
\hline \multicolumn{1}{c}{ Average } & & & &
\end{tabular}

To find out the overall average percentage above, it can be seen after going through the calculation of the weighted score of answer A weights 4, answer B has another weight of 3, answer $\mathrm{C}$ has a weight of 2 , and $\mathrm{D}$ weights of 1 .Thus based on the recapitulation of the results of the teacher's role in internalizing the values of local wisdom in learning at Madrasah Ibtidaiyah, Cirebon City option C is $56.6 \%$ and option D is $41.6 \%$, it means that the role of teachers in internalizing local wisdom values in learning is categorized as not good.

The teacher factor in learning is an important factor that determines the success or failure of a learning process. However good the other factors are as components of a learning process, if they are not supported by professional teacher factors, it will be difficult to realize the expected success, and vice versa. Purwanto (2000) emphasized that the teacher is a key factor in the successful learning activity. The teacher is the front line that encourages the achievement of learning effectiveness.

The role of the teacher in teaching, one of which is how to develop the learning process by internalizing the values of local wisdom. Teachers in Cirebon City have an important task in overseeing the internalization of local wisdom values. As in the fact that Cirebon has a lot of local wisdom starting from the palace, the Sunyaragi Cave cultural heritage, heirlooms and historical relics, Pasarean Gunung Djati, gamelan, dances, batik, music, to songs and others, all are necessary for maintaining its existence and sustainability.

Through learning at Madrasah Ibtidaiyah, teachers are required to be able to internalize the values of local wisdom. The substance of local wisdom can be stated in the lesson plan, as well as in the development of learning materials, media, methods, and strategies. All learning processes can be used as a means of internalizing local wisdom values. Apart from the 
learning process, schools may support their citizens to make cultural visits to gain insights related to the existence and preservation of local wisdom. Whereas when we discuss the role of the teacher, as stated by Bishop et al., (2020) that the roles of the teachers in a personalized learning environment illustrates the need for teacher roles that empower students in the learning process, scout student interests and resources to support their learning, scaffold emergent projects, and assess diverse forms of student work. Some of these roles are very possible to be connected with local wisdom around students. Therefore, schools that intend to implement personalized learning must pay attention to internal and external norms and expectations for the various roles that teachers play in the learning lives of elementary school students.

Even so, the internalization of local wisdom values in learning in the Madrasah Ibtidaiyah in Cirebon City is not as smooth as imagined. It shows that teachers are considered less able to internalize the values of local wisdom. Based on the results of the analysis it was stated that the teachers did not understand what kinds of local wisdom were. As a result of the lack of understanding of local wisdom, it has an impact on the quality of learning development based on local wisdom. Teachers are less interested in internalizing the values of local wisdom, apart from not being motivated to introduce local wisdom to the younger generation, they are also unable to explain the kinds and philosophical meanings of local wisdom.

Teachers' understanding of the types and significance and philosophical meanings of each local wisdom will greatly impact how and to what extent teachers master local wisdom. When teachers master local wisdom, it means that a teacher has good competence in terms of mastery of the material (Shufa, 2018). Therefore, it cannot be argued that if a teacher experiences weakness in the field of mastery of the material, then the teacher must as soon as a possible increase in quality through coaching and training efforts. Coaching and training for teachers related to local wisdom, teachers are encouraged to read a lot, observe, make inquiries, make visits and have lots of discussions with cultural observers in Cirebon.

Teachers can develop local wisdom in learning through steps in the form of identification of local wisdom that develops in the local community, determining the functions and objectives of internalizing a variety of related local wisdom, determining criteria for study materials that are tailored to the character of students, and compiling a curriculum in the form of determining local excellence which outlined in the syllabus (Nadlir, 2016). The inculcation of local wisdom values can be done by the teacher by integrating it into the learning model. As the research of Wijayanthi et al. (2014) integrates the local 
wisdom of the local community with the guided inquiry learning model, it influences the responsibility and learning outcomes of students. This is because local wisdom is local ideas, values, and views that can last a long time and are wise in people's lives so that if implemented in a learning process it will form a strong character (Nadlir, 2016; Wijayanthi et al., 2014). Local wisdom-based learning also has benefits for disaster mitigation, as research by Desfandi (2016) states that almost all regions of Indonesia are prone to disasters so that proper efforts are needed to accommodate the local wisdom of local communities in dealing with disasters.

\section{Factors Affecting the Role of Teachers in Internalizing Local Wisdom Values}

The role of teachers in internalizing the values of local wisdom in social studies learning at Madrasah Ibtidaiyah, Cirebon City is influenced by two factors, namely factors that support and hinder. Explicitly how these factors can be seen in the following description.

Tabel 4. Recapitulation of Supporting Factors for the Cultivation of Local Wisdom Values in Learning at Madrasah Ibtidaiyah, Cirebon

\begin{tabular}{lccccc}
\hline \multicolumn{1}{c}{ Indicator } & \multicolumn{4}{c}{ Alternative Answer } & Sum \\
\cline { 1 - 5 } & A & B & C & D & $(\%)$ \\
\hline Government regulations & 15 & 75 & 10 & 0 & 100 \\
The Existence of Local Wisdom & 25 & 75 & 0 & 0 & 100 \\
Cultural Site Mileage & 40 & 50 & 10 & 0 & 100 \\
Principal Support & 20 & 60 & 20 & 0 & 100 \\
Relevance of Teaching Material & 25 & 75 & 0 & 0 & 100 \\
\hline \multicolumn{1}{c}{ Sum } & 125 & 335 & 40 & 0 & 100 \\
\hline \multicolumn{1}{c}{ Average } & 25 & 67 & 8 & 0 & 100 \\
\hline
\end{tabular}

Supporting factors for the role of teachers in internalizing local wisdom values in learning are categorized as good. This means that in general the role of teachers in the Madrasah Ibtidaiyah of Cirebon city has been supported by clear government regulations, the availability of adequate local wisdom, adequate mileage, good principal support, and conformity between teaching materials and local wisdom values in internalizing the values. the value of local wisdom to students through learning well.

Table 5. Recapitulation of Inhibiting Factors for the Cultivation of Local Wisdom Values in Learning at Madrasah Ibtidaiyah, Cirebon

\begin{tabular}{llllll}
\hline \multicolumn{1}{c}{ Indicator } & \multicolumn{4}{c}{ Alternative Answer } & Sum \\
\cline { 1 - 5 } & A & B & C & D & $(\%)$ \\
\hline Actualization Budget & 0 & 0 & 20 & 80 & 100 \\
Condition of Teaching Materials & 0 & 15 & 60 & 25 & 100 \\
Cultural Site Entrance Fee & 0 & 0 & 20 & 80 & 100 \\
Teacher's understanding & 0 & 0 & 40 & 60 & 100 \\
Parental Support & 0 & 0 & 65 & 35 & 100 \\
\hline \multicolumn{1}{c}{ Sum } & 0 & 15 & 205 & 280 & 100 \\
\hline \multicolumn{1}{c}{ Average } & 0 & 3 & 41 & 56 & 100 \\
\hline
\end{tabular}


Inhibiting factors for the role of teachers in internalizing the values of local wisdom in learning at Madrasah Ibtidaiyah, Cirebon City, option D is 56\% and option C is $41 \%$, means that the teacher's role in internalizing the values of local wisdom in learning is categorized as lacking good. This is due to obstacles in the form of budget constraints, lack of understanding of teachers, expensive entrance tickets, weak parental support, and so on.

The government policy factor towards internalizing local wisdom can be in the form of regulations which are an important stepping stone for efforts to instill local wisdom values in learning. With the issuance of government regulations concerning the importance of teaching and inculcating the values of local wisdom among the younger generation, it means that in addition to teaching and cultivating local wisdom values, it is also considered very important in its implementation by having a clear legal umbrella or formal legalization. Whomever the teacher is, and in any school, he is obliged to appreciate and instill the values of local wisdom in learning.

According to Oktaviant. et al. (2017) that the success of a learning process is determined by many things, one of which is how good the competence of the teacher is in learning. Teacher competence can be translated well if it is supported by clear laws and regulations, as well as support from the school community, the condition of teaching materials, the existence of school mileage, and so on. All of these factors are important pillars for the achievement of the effectiveness of inculcating local wisdom values.

Apart from the supporting factors, the role of the teacher is also influenced by how the obstacles surround it. The high admission ticket for cultural heritage, the weak support of school principals, parents, as well as low understanding among teachers of local wisdom is a problem in itself for the realization of the optimal cultivation of local wisdom values in the Madrasah Ibtidaiyah in Cirebon. In the interests of preserving the nation's culture, the government, schools, and managers of local wisdom should synergize to make it easy for the younger generation to be close, to know, to understand so that they love the nation's cultural treasures.

Cirebon is a city that has a lot of local wisdom. If there is no special handler and caring from competent parties, then wait for it to be full. In fact, throughout history, it is believed that the measure of the integrity of a society and a nation depends on how much appreciation is given to the work of its ancestors. The better the appreciation was given to the cultural heritage of the ancestors, the better the impact on the integrity of the cultural heritage in the form of local wisdom, and vice versa. 


\section{CONCLUSION}

The teacher's role in internalizing the values of local wisdom in Cirebon is in the category of still lacking. The factors that influence the role of teachers in internalizing the values of local wisdom are divided into two things, namely factors that support and hinder. The supporting factors for the role of teachers in the Madrasah Ibtidaiyah of Cirebon city include the existence of clear government regulations, a wealth of local wisdom, adequate mileage, good school principal support, and conformity between teaching materials and local wisdom values in internalizing the values of local wisdom in students. Through learning. While the inhibiting factors were found in the form of the absence of a special budget, teaching materials that have not been integrated with Cirebon local wisdom, high entrance fees for cultural heritage, weak parental support, and low understanding among teachers of Cirebon local wisdom. Hopefully, in the future, the Madrasah Ibtidaiyah's teachers will begin to integrate Cirebon local wisdom in learning, for example by providing teaching materials based on local wisdom. This study contributes to the world of education, especially the Madrasah Ibtidaiyah by providing an overview of the importance of the role of teachers in internalizing local wisdom so that it can become a reference for further research on how it is applied in learning. In addition, it also provides an overview of the importance of cultural inheritance so that appreciation can be further enhanced so that good values remain grounded in the wider community.

\section{REFERENCES}

Alexon, A., \& Sukmadinata, N. S. (2010). Pengembangan Model Pembelajaran Terpadu Berbasis Budaya Untuk Meningkatkan Apresiasi Siswa Terhadap Budaya Lokal. Jurnal Cakrawala Pendidikan, 2(2), 189-203. https://doi.org/10.21831/cp.v2i2.339

Amsyari, F. (2016). Masa Depan Umat Islam Indonesia Peluang dan Tantangan. Mizan.

Arovah, E., Lubis, N., Dienaputra, R., \& Nugrahanto, W. (2017). Wèwèkas dan Ipat-ipat Sunan Gunung Jati beserta Kesesuaiannya dengan Al-Quran. Patanjala, 9(3), 375390.

Bishop, P. A., Downes, J. M., Netcoh, S., Farber, K., Demink-Carthew, J., Brown, T., \& Mark, R. (2020). Teacher roles in personalized learning environments. Elementary School Journal, 121(2). https://doi.org/10.1086/711079

Darmawan, O. (2016). Penanaman Budaya Anti Kekerasan Sejak Dini pada Pendidikan Anak Melalui Kearifan Lokal Permainan Tradisional (Instill Anti-Violence Culture At Early Stage of children Education Through Local Wisdom Of Traditional Games). Jurnal HAM, 7(2), 111. https://doi.org/10.30641/ham.2016.7.175

Desfandi, M. (2016). Urgensi Kurikulum Pendidikan Kebencanaan Berbasis Kearifan Lokal Di Indonesia. SOSIO DIDAKTIKA: Social Science Education Journal, 1(2). https://doi.org/10.15408/sd.v1i2.1261 
Fatro, M. Z., Sulistyo, E. T., \& Nugroho, S. (2019). Internalization of Local Wisdom Value through I-Spring Technology-Based Art and Culture Learning. Lekesan: Interdisciplinary Journal of Asia Pacific Arts, 2(1), 8-11. https://doi.org/10.31091/lekesan.v2i1.748

Gunawan, I., \& Sulistyoningrum, R. T. (2017). Menggali Nilai-Nilai Keunggulan Lokal Kesenian Reog Ponorogo Guna Mengembangkan Materi Keragaman Suku Bangsa Dan Budaya Pada Mata Pelajaran Ips Kelas Iv Sekolah Dasar. Premiere Educandum : Jurnal Pendidikan Dasar Dan Pembelajaran, 3(01), 50-87. https://doi.org/10.25273/pe.v3i01.59

Halim, E. N., Stefanni, C., \& Dwiputra, K. (2018). Urup Lamp : Wood Table Lamp Berbahan Dasar Kayu Limbah Produksi dengan Falsafah Hidup Orang Jawa. Seminar Nasional Seni Dan Desain: "Konvergensi Keilmuan Seni Rupa Dan Desain Era 4.0” FBS Unesa, $25 \quad$ Oktober 2018, 1, 91-97. https://proceedings.sendesunesa.net/media/266853-urup-lamp-wood-table-lampberbahan-dasar-b0e95c8d.pdf

Hutama, F. S. (2017). Pengembangan Bahan Ajar Ips Berbasis Nilai Budaya Using Untuk Siswa Sekolah Dasar. JPI (Jurnal Pendidikan Indonesia), 5(2), 817. https://doi.org/10.23887/jpi-undiksha.v5i2.8359

Jumriani, J., Mutiani, M., Putra, M. A. H., Syaharuddin, S., \& Abbas, E. W. (2021). The Urgency of Local Wisdom Content in Social Studies Learning: Literature Review. The Innovation of Social Studies Journal, 2(2), 103. https://doi.org/10.20527/iis.v2i2.3076

Komariah, S. (2011). Kearifan Lokal pada Masyarakat Cirebon. SOSIETAS Jurnal Pendidikan Sosiologi, 1(1). https://doi.org/10.17509/sosietas.v1i1.1112

Leming, J. (2008). Research and practice in moral and character education: Loosely Coupled Phenomena (In L. P. N). Routledge.

Miles, M. ., Huberman, A., \& Saldana, J. (2014). Qualitative Data Analysis, A Methods Sourcebook. SAGE Publication.

Miller, T. W., Kraus, R. F. ., \& Veltkamp, L. J. (2005). Character education as a prevention strategy in school-related violence. Journal of Primary Prevention, 26, 455-466.

Moleong, L. J. (2014). Metode Penelitian Kualitatif Edisi Revisi. Remaja Rosdakarya.

Mubarok, I., \& Rahmatulloh, I. N. (2020). The Urgency of Strengthening Character Education in Elementary Schools Through Local Wisdom in the Industrial Revolution Era 4.0. International Consortium of Education and Culture Research Studies (ICECRS). https://doi.org/https://doi.org/10.21070/icecrs2020448

Nadlir, M. (2016). Urgensi Pembelajaran Berbasis Kearifan Lokal. Jurnal Pendidikan Agama Islam. Jurnal Pendidikan Agama Islam, 2(2), 2299-2300. https://doi.org/https://doi.org/10.15642/jpai.2014.2.2.299-330

Naryatmojo, D. L. (2019). Internalization of the Concept of Local Wisdom for Students in the Listening Class. Arab World English Journal (AWEJ), 10(1), 382-394. https://doi.org/10.24093/awej/vol10no1.31

Oktaviant., I., Zuliana, E., \& Ratnasari, Y. (2017). Menggagas Kajian Kearifan Budaya Lokal di Sekolah Dasar Melalui Gerakan Literasi Sekolah. Seminar Nasional: Aktualisasi Kurikulum 2013 Di Sekolah Dasar Melalui Gerakan Literasi Sekolah Untuk Menyiapkan Generasi Unggul Dan Berbudi Pekerti, 35-42. https://doi.org/10.1016/j.jff.2008.09.012 
Purwanto, M. N. (2000). Ilmu Pendidikan Teoritis dan Praktis. Remaja Rosdakarya.

Puspitasari, R. (2012). Pengembangan Nilai-Nilai IPS dalam pendidikan alternatif bagi anak nelayan di kota Cirebon. Jurnal Edueksos, I(2), 33-48.

Relin, R., W., R. I., \& S, B. W. (2018). Local Wisdom Values in Balinese Folktales That Are Relevant to Character Education for the First Grade at Primary School. Journal of Language Teaching and Research, 9(1), 155. https://doi.org/10.17507/j1tr.0901.20

Rokhamana, S., \& Yuliati. (2014). Character Education For Golden Generation 2045 (National Character Building for Indonesian Golden Years). Procedia-Social and Behavioral Sciences, 141, 1161-1165.

Shufa, N. K. F. (2018). Pembelajaran Berbasis Kearifan Lokal Di Sekolah Dasar: Sebuah Kerangka Konseptual. Jurnal Ilmiah Kependidikan, 1(1), 48-53.

Sukmadinata, N. S. (2005). Landasan Psikologi Proses Pendidikan. Remaja Rosdakarya.

Utari, U., Degeng, I. N. S., \& Akbar, S. (2016). Di Sekolah Dasar Dalam Menghadapi Masyarakat Ekonomi Asean ( Mea ). Jurnal Teori Dan Praksis Pembelajaran IPS, 1(1), 39-44.

Wagiran. (2012). Pengembangan Karakter Berbasis Kearifan Lokal Hamemayu Hayuning Bawana. Pendidikan Karakter, 2(3), 329-339. https://doi.org/10.21831/jpk.v0i3.1249

Wijayanthi, A. . S. O. V., Lasmawan, I. W., \& Natajaya, I. N. (2014). No TitlePengaruh Model Pembelajaran Inkuiri Terbimbing Berbasis Kearifan Lokal Terhadap Tanggung Jawab dan Hasil Belajar IPS Siswa Kelas V SD Gugus I Gusti Ngurah Rai Denpasar Selatan. Jurnal Pendidikan Dasar Ganesha, 4(1), 1-12. 